\title{
IMPACT OF THE INTERNATIONAL GLACIOLOGICAL SOCIETY ON THE DEVELOPMENT OF GLACIOLOGY AND ITS FUTURE ROLE
}

\author{
By J. WEERTMAN \\ (Department of Materials Science and Engineering, Materials Research Center, and \\ Department of Geological Sciences, Northwestern University, Evanston, Illinois 60201, U.S.A.)
}

\begin{abstract}
After the end of World War II glaciology entered a new golden age, which has yet to end. The quality of this golden age is comparable to the classic period of the nineteenth century. The International Glaciological Society has been the major catalyst, through its very active and co-operative international membership and its Journal of Glaciology in setting the modern major advances in the science of glacier and ice phenomena in motion and sustaining them.
\end{abstract}

AFTER the end of World War II glaciology entered a new golden age, which has yet to end. The quality of this golden age is comparable to the classic period of the nineteenth century. The International Glaciological Society (IGS) has been the major catalyst, through its very active and co-operative international membership and its Journal of Glaciology, in setting the modern major advances in the science of glacier and ice phenomena in motion and sustaining them. The precursor of this surge in glaciological knowledge was the research, just before World War II, of the founder of the Society, Gerald Seligman, and his associates (Seligman, 1941). Much credit must go to the leaders of the British Glaciological Society for the foresight that led them to change the British Glaciological Society (BGS) into the international organization in which the science of glaciology has made its major advances. (The history of the International Glaciological Society has recently been told by Peter Wood (1986).)

I believe it is unique in the history of scientific societies for a national society to become transformed into an international society. This is what happened to the British Glaciological Society (whose original name was the Association for the Study of Snow and Ice), which is now the International Glaciological Society and whose fiftieth anniversary we are now celebrating. The BGS actually had been working so well in the interests of international glaciology that perhaps it seemed unwise to go against the folk wisdom "if it ain't broke, don't fix it" by changing into an international society. (The membership of the IGS from its beginning was drawn from many countries besides the United Kingdom. One need only examine the list of new members in old issues of the Journal of Glaciology and of Ice to see the largely international flavor of the membership.) The international glaciological community will forever be indebted to the leaders of the British Glaciological Society. They actually encouraged this metamorphism of their organization.

The early issues of the Journal of Glaciology and of Ice give some of the reasons why this transformation came about. In the Foreword to the first issue of the Journal of Glaciology, Hans Ahlmann (1947), a Swede, stated that "The British Glaciological Society is the only society in the world which safeguards our knowledge of snow, ice and glaciers ...". (This was stated at a time, just after World War II, when the Zeitschrift für Gletscherkunde had ceased publication.) The Editorial Committee (1947) pointed out immediately after the Foreword that "the demand for an international journal devoted entirely to glaciology has become greater than ever. In the absence of such a journal the hope was expressed in this country, in the United States and on the Continent that this Society should take the initiative in bringing one into being." It is clear that at a very early period in the history of the IGS its leaders were quite visionary in their plans for advancing glaciology.

The major impact of the IGS probably came from the impact of its Journal of Glaciology on the worldwide glaciological community. If a new researcher reads (and understands!) only the papers published in the Journal of Glaciology, from its early issues to the present, that researcher will have a reasonably complete understanding of the field of glaciology and of the experimental, theoretical, and field work that led to our present knowledge. Moreover, the researcher will know what the state of glaciology was at any period from the middle of the 1940s to the present.

The earliest issues of the Journal set the stage for the post-war glaciological outburst. Important results of the prewar and post-war Seligman research projects at the Jungfraujoch in Switzerland are set forth. For example, Max Perutz, who was later to win a Nobel prize in a different area of science, presented the direct evidence obtained from a bore hole in Jungfraugletscher of the differential flow motion produced by the creep of ice within a glacier (Perutz, 1950). He even published a creep curve of ice based on the differential motion revealed by the change of inclination of the bore hole (Perutz, 1950). The differential flow observations laid to rest Rudolf Streiff-Becker's extrusion-flow model of glacier flow (Seligman, 1947; Streiff-Becker, 1953). (Extrusion flow of ice in a glacier was imagined to occur in a manner similar to squeezing toothpaste out of a tube. The usual objection raised to extrusion flow, that it is physically impossible, actually is not a valid one. Something like extrusion flow must occur near the edges of floating ice shelves when the upper ice layers are much colder than the bottom ice layers. The upper ice layers, because of their colder temperature, are, like a toothpaste tube, more difficult to deform plastically.) Perutz also described the famous wartime iceberg aircraftcarrier project which, although never carried to completion, brought home the importance of the rheological properties of ice for understanding glacier flow (Perutz, 1948).

The early issues of the Journal of Glaciology saw accounts of glaciological research carried out in various parts of the world by numerous glaciologists from the international community. Many well-established glaciologists of the pre-war generation found it desirable to publish in the Journal. The German glaciologist, Richard Finsterwalder, for example, gave an account of his work on Jostedalsbreen in Norway (Finsterwalder, 1951). Swiss glaciological research was described by Robert Haefeli, a Swiss glaciologist (Haefeli, 1948), including his own research results on the creep closure of a tunnel dug into the ice at Jungfraujoch 
(Haefeli, 1952). Another Swiss, André Renaud, discussed work on ice grains in glacier ice. He showed that each grain is surrounded with a saline film (Renaud, 1949). An Icelander, Jón Eythórsson, described the variation of the sizes of Icelandic glaciers (Eythórsson, 1949). Another Icelander, Sigurdur Thorarinsson (1953), also published on the glacier water outbursts of Grimsvötn. Douglas Mason, an Englishman, presented results of British work on the Larsen Ice Shelf in Antarctica (Mason, 1950). The advance and retreat of New Zealand glaciers were correlated with precipitation records by Suggate (1950). Robert Sharp, an American, gave a nice review and descriptions of valley glaciers as well as a detailed account of some of the work on Upper Seward Glacier in the Yukon, Canada (Sharp, 1948, 1951). Henri Bader, the Swiss/American glaciologist, presented the first paper that led to the present extensive study of the gases in air bubbles trapped in glacier ice (Bader, 1950). Vincent Schaefer, the General Electric Co. scientist of cloud-seeding fame, presented the new replica technique of studying ice crystals (Schaefer, 1950), work he did at Weissfluhjoch in Switzerland. The Journal had short articles with the splendid drawings that illustrated glacial phenomena of the Swiss, Streiff-Becker (1951). The renowned Japanese snow scientist, Ukichiro Nakaya, gave his account of an electron-microscope study of snow-crystal nuclei which showed that each snow crystal always has one solid nucleus (Nakaya, 1951). He later showed that even the snowflakes that fall out of the clean skies over Hawaii require solid nuclei for their formation (Nakaya, 1959). The Russian, Petr Shumskiy (1957), gave an account of Russian post-war activities in Antarctica. And so on.

One of the early issues of the Journal carried an account of the joint meeting of the IGS with the British Rheological Club and the Institute of Metals at which Egon Orowan, one of the originators of the crystal dislocation, presented the now well-known theoretical profile of an ice cap or ice sheet found from the assumption that ice can be considered to approximate a perfectly plastic solid. There, Perutz discussed his field observation of creep flow of glacier ice (British Glaciological Society, 1949). The discussion of plastic flow was continued by Finsterwalder in a later paper published in the Journal (Finsterwalder, 1950). This joint meeting, which considered both the high-temperature plastic behavior of ice and the plastic flow of glaciers, actually was the first step that led to a very long series of papers in the Journal of Glaciology and other journals by many investigators from many lands on experiments on the creep of ice and about theories of the flow by creep of glaciers and ice sheets. The name that immediately comes to mind on the former topic is that of John Glen, and on the latter topic is that of John Nye, both British physicists/glaciologists. Although the longer accounts of the Glen and the Nye early work appeared in journals other than the Journal of Glaciology, their initial reports were in the Journal.

Glen (1952) carried out the first really comprehensive set of experiments on the high-temperature creep of ice. His experimentally determined creep law for ice (the same law is found in metals and other crystalline materials) has been used ever since in glacier-flow theories. Others from around the world, starting with the Swiss scientist Samuel Steinemann (1954), have further advanced our knowledge of the creep of ice. The first experiments on the effect of hydrostatic pressure on the creep of ice were reported by George Rigsby (1958). Today, this subject has turned exotic. It is actually possible to prove experimentally, as was done by the Japanese scientist Hitoshi Shoji and the American scientist Chester Langway, that the ice deposited during the last ice age (the Wisconsin) of the Pleistocene actually is appreciably plastically softer than the more recent Holocene ice (Shoji and Langway, 1985). This result, as the Danish glaciologist Niels Reeh (1985) has pointed out, may play an important part in how ice ages come and go. Nye (1952[a], [b]), as all but perhaps the most recent members of the IGS know, started, developed, and solved the major fraction of the theoretical solutions of problems of glacier flow, including the flow of ice sheets and ice caps. The subsequent history of the theory of the flow of glaciers, ice sheets, and ice shelves, which has been developed extensively by many glaciologists around the world, has been well described in the texts of the IGS members Stan Paterson (1969, 1981), a Canadian; Louis Lliboutry (1964-65), a Frenchman; Petr Shumskiy (1955), a Russian; Sharp (1953, 1954); and - David Drewry (1986), an Englishman.

The Journal of Glaciology saw the early publication on topics that continue to remain of active interest to the present time. The Frenchman, Albert Bauer (1955) made perhaps the first estimate of the mass balance of the Greenland ice sheet. Malcolm Mellor (1959), an Australian/ American, made a similar early estimate for a part of Antarctica. The first rational theoretical estimate of what should be the depth of crevasses also appeared in the Journal (Nye, 1955). The Journal contains the early (as well as later) papers by many IGS members who made significant contributions in some speciality in glaciology. For example, Wilford Weeks with Donald Anderson, both Americans, published work on sea ice (Weeks and Anderson, 1958). Another sea-ice expert, the Austrian/American, Norbert Untersteiner published early in the Journal, although his first papers were not on sea ice (Untersteiner, 1955). The Australian/Briton, Gordon Robin (1955) gave the first reasonably complete theoretical treatment of the temperature distribution in glaciers and ice sheets. The American, Harry Wexler (1960) analyzed the heating and melting of the Ross Ice Shelf. The problem of heat balance of Alpine glaciers was attacked by the Austrian scientist, Herfried Hoinkes (1955). The Australians William Budd, Richard Jenssen, and Uwe Radok developed the first numerical modeling computer calculations of ice-sheet flow and heat fluxes within them (Jenssen and Radok, 1963). The Swiss avalanche expert, Andre Roch (1954), and the American avalanche expert, Edward LaChapelle (1960), contributed to the Journal. And so it goes.

Results of two seminal post-war scientific expeditions, one in the Arctic and one in the Antarctic, were reported in early issues of the Journal. The preliminary glaciological and seismic results of the international Norwegian-BritishSwedish Antarctic Expedition (1949-52), were described by the Swede, Valter Schytt (1953) and by Gordon Robin (1953). Detailed accounts of the results of the Arctic Institute of North America expeditions to Baffin Island of 1950 and 1953, whose personnel included Canadian, British, Swiss, and Norwegian scientists, were given in articles by Patrick Baird (1952), Svenn Orvig (1953), Hans Röthlisberger (1955), William Ward (1952[a], [b], 1954, 1955), and Ward and Baird (1954). On a much smaller scale, the Vaughan Lewis-led British study of Norwegian cirque glaciers set an extremely high standard on how field studies of glaciers should be carried out (Lewis, 1960; McCall, 1952).

The researches of the Norwegian-British-Swedish Antarctic Expedition and the Baffin Island expeditions are notable because they were strongly influenced by (and in turn strongly influenced) the emerging post-war theoretical glaciology. The framework of subsequent glaciological work in the Antarctic and in Greenland was largely set by the example of the polar researches of these well-known members of the IGS. For example, the very successful seismic ice-sounding studies of the Antarctic, which were begun by the Norwegian-British-Swedish Antarctic Expedition, and carried further by the American scientist Albert Crary during the IGY, culminated in the discovery by the Americans, Charles Bentley, Crary, and others that a major fraction of the base of the West Antarctic ice sheet is situated well below sea-level. (The base is so far below sea-level that if the ice sheet were removed and rebound took place it would still be below sea-level.) Because the base is below sea-level, this ice sheet may be unstable. The stability question of the West Antarctic ice sheet has received a great deal of theoretical attention, principally from Terence Hughes of the University of Maine, in recent years. The stability question has been the partial justification of recent Antarctic field work. Shumskiy (1959), interestingly, raised the question of whether Antarctica is a continent or an archipelago in one of the issues of the Journal of Glaciology.

Early issues of the Journal of Glaciology contain initial reports of other research areas that were later to dominate the attention of the glaciological world. One glamorous area 
of glaciological research is the deep ice-core drilling programs of present and recent times. Very exciting results have and are being obtained about Holocene and Pleistocene climates. A short note in the Journal by Chester Langway (1958), who is one of the founding fathers of ice-core deep drilling, on a $400 \mathrm{~m}$ deep ice core obtained in Greenland was, in retrospect, the announcement that a new and qualitatively different glaciological research area had come into being. The Dane, Willy Dansgaard, the Swiss, Hans Oeschger, and the Frenchman, Claude Lorius, in particular, have had immense success in extracting very intriguing climatic information from the deep ice cores. Remote sensing, including radar sounding of ice thickness, is another area that has grown along with the Journal (see Jay Zwally's (1987) paper in this volume).

Symposia organized by the IGS on special glaciological topics have played a strong role in the development of glaciology. Early conferences received brief write-ups in the Journal (British Glaciological Society, 1949; Symposium 1951[a], [b]). Later ones, such as the 1977 one on the physics and chemistry of ice (Symposium, 1978) and the 1974 one on remote sensing (Symposium, 1975), required thick volumes of the Journal for their contents. Eventually, both the proceedings of IGS-organized symposia, and the proceedings of glaciological symposia organized by other bodies, were published in a new journal of the Society, Annals of Glaciology. These conferences and conference proceedings enable glaciologists from around the world to present for some speciality a very useful state-of-the-art record, summaries of past accomplishments, significant new results, and, perhaps most important of all, new directions for the field. The 1978 Ottawa glacier-bed symposium, organized by the National Research Council of Canada and published in the Journal (Symposium, 1979), is a prime example of pushing a field on to a new path. The topic of that glacier-bed symposium was the glacier-bed ice-rock interface. But a paper presented at Ottawa by Geoffrey Boulton (1979), now at the University of Edinburgh, was concerned with glacier ice moving over a deformable bed. And at the present time the deformable glacier-bed problem is one of the most interesting areas in glacier mechanics. This problem was a strong focus in the recent Whistler Village, British Columbia, Canada, conference on fast glacier flow sponsored by the American Geophysical Union, and the Interlaken, Switzerland, conference on basal water pressure sponsored by the Eidgenössiche Technische Hochschule (ETH) of Zürich (both conferences were organized primarily by members of the IGS). The University of Wisconsin results from Ice Stream B, which partly drains the West Antarctic ice sheet, show that this ice stream moves over a deformable bed (Alley and others, 1986; Blankenship and others, 1986); (Since these Ice Stream B results were obtained with seismic techniques, they might be regarded as a late return of a signal sent by the Norwegian-British-Swedish Antarctic Expedition mentioned earlier in this paper.)

\section{CONCLUSION}

The International Glaciological Society has had a strong impact on glaciology from its start. Just after World War II its journal, Journal of Glaciology, became the chief journal where glaciological results appeared. It welcomed into its membership scientists from any country. (Only currency transfer restrictions appear to limit membership from some countries with significant numbers of glaciologists.) As a consequence, the IGS came into the favorable position of being inside a sort of Catch-22 loop rather than in the unfavorable position of being outside such a loop. The researcher who published in the Journal of Glaciology knew his or her paper would be seen by the international glaciological community in a journal of the highest editorial and refereeing standards. As a result, the Journal attracts a world-wide membership of people who are prime movers and shakers in glaciology. In turn, the published research of these members continues to make the Journal outstanding and an attractive one in which to publish.

Another, perhaps more important, factor is behind the large impact of the IGS on glaciology. The international glaciological community is rather small, compared with, say, the physics or chemistry community in any medium to large advanced country. As a consequence, a vibrant international glaciological organization is essential to bring into being, to catalyze, that critical interaction of scientists which makes a scientific discipline exciting to be in and which leads to exciting discoveries. Wonderful advances in glaciology have taken place and continue to occur since the founding of the Society. In no small measure is this a consequence of the healthy glaciological climate created by the International Glaciological Society.

\section{ACKNOWLEDGEMENT}

This research was sponsored in part with funding from the Climate Dynamics Section of the National Science Foundation under grant ATM-83-06251.

\section{REFERENCES}

Ahlmann, H.W. 1947. Foreword. Journal of Glaciology, Vol. 1, No. 1, p. 3-4.

Alley, R.B., and others. 1986. Deformation of till beneath ice stream B, West Antarctica, by R.B. Alley, D.D. Blankenship, C.R. Bentley, and S.T. Rooney. Nature, Vol. 322, No. 6074, p. 57-59.

Bader, H. 1950. The significance of air bubbles in glacier ice. Journal of Glaciology, Vol. 1, No. 8, p. 443-51.

Baird, P.D. 1952. The glaciological studies of the Baffin Island Expedition 1950. Part 1: Method of nourishment of the Barnes Ice Cap. Journal of Glaciology, Vol. 2, No. 11, p. 2-9.

Bauer, A. 1955. The balance of the Greenland ice sheet. Journal of Glaciology, Vol. 2, No. 17, p. 456-62.

Blankenship, D.D., and others. 1986. Seismic measurements reveal a saturated porous layer beneath an active Antarctic ice stream, by D.D. Blankenship, C.R. Bentley, S.T. Rooney, and R.B. Alley. Nature, Vol. 322, No. 6074, p. 54-57.

Boulton, G.S. 1979. Processes of glacier erosion on different substrata. Journal of Glaciology, Vol. 23, No. 89, p. $15-38$.

British Glaciological Society. 1949. Joint Meeting of the British Glaciological Society, the British Rheologists' Club and the Institute of Metals. Journal of Glaciology, Vol. 1, No. 5 , p. 231-40.

Drewry, D. 1986. Glacial geologic processes. London, Edward Arnold.

Editorial Committee. 1947. "The Journal of Glaciology". Journal of Glaciology, Vol. 1, No. 1, p. 4.

Eythórsson, J. 1949. Variations of glaciers in Iceland 1930-47. Journal of Glaciology, Vol. 1, No. 5, p. $250-52$.

Finsterwalder, R. 1950. Some comments on glacier flow. Journal of Glaciology, Vol. 1, No. 7, p. 383-88.

Finsterwalder, R. 1951. The glaciers of Jostedalsbreen. Journal of Glaciology, Vol. 1, No. 10, p. 557-58.

Glen, J.W. 1952. Experiments on the deformation of ice. Journal of Glaciology, Vol. 2, No. 12, p. 111-14.

Haefeli, R. 1948. The development of snow and glacier research in Switzerland. Journal of Glaciology, Vol. 1, No. 4, p. 192-201.

Haefeli, R. 1952. Observations on the quasi-viscous behaviour of ice in a tunnel in the Z'Mutt Glacier. Journal of Glaciology, Vol. 2, No. 12, p. 94-99.

Hoinkes, H. 1955. Measurements of ablation and heat balance on Alpine glaciers. Journal of Glaciology, Vol. 2, No. 17 , p. 497-501.

Jenssen, D., and Radok, U. 1963. Heat conduction in thinning ice sheets. Journal of Glaciology, Vol. 4, No. 34, p. 387-97.

LaChapelle, E.R. 1960. Recent progress in North American avalanche forecasting and control. Journal of Glaciology, Vol. 3, No. 28, p. 679-85.

Langway, C.C., jr. 1958. A 400 meter deep ice core in Greenland - preliminary report. Journal of Glaciology, Vol. 3, No. 23, p. 217.

Lewis, W.V., ed. 1960. Investigation on Norwegian cirque glaciers. London, The Royal Geographical Society. 
Lliboutry, L. 1964-65. Traité de glaciologie. Paris, Masson et Cie. 2 vols.

McCall, J.G. 1952. The internal structure of a cirque glacier; report on studies of the englacial movements and temperatures. Journal of Glaciology, Vol. 2, No. 12, p. $122-31$.

Mason, D. 1950. The Larsen Shelf Ice. Journal of Glaciology, Vol. 1, No. 8, p. 409-13.

Mellor, M. 1959. Mass balance studies in Antarctica. Journal of Glaciology, Vol. 3, No. 26, p. 522-33.

Nakaya, U. 1951. Snow crystal growth. Journal of Glaciology, Vol. 1, No. 10, p. 550.

Nakaya, U. 1959. Snow crystals observed at Mauna Loa. Journal of Glaciology, Vol. 3, No. 25, p. 364-67.

Nye, J.F. 1952[a]. A comparison between the theoretical and measured long profile of the Unteraar Glacier. Journal of Glaciology, Vol. 2, No. 12, p. 103-07.

Nye, J.F. 1952[b]. The mechanics of glacier flow. Journal of Glaciology, Vol. 2, No. 12, p. 82-93.

Nye, J.F. 1955. Comments on Dr. Loewe's letter and notes on crevasses. Journal of Glaciology, Vol. 2, No. 17, p. 512-14.

Orvig, S. 1953. The glaciological studies of the Baffin Island Expedition, 1950. Part V. On the variation of the shear stress on the bed of an ice cap. Journal of Glaciology, Vol. 2, No. 14, p. 242-47.

Paterson, W.S.B. 1969. The physics of glaciers. Oxford, etc., Pergamon Press.

Paterson, W.S.B. 1981. The physics of glaciers. Second edition. Oxford, etc., Pergamon Press. (Pergamon International Library.)

Perutz, M.F. 1948. A description of the iceberg aircraft carrier and the bearing of the mechanical properties of frozen wood pulp upon some problems of glacier flow. Journal of Glaciology, Vol. 1, No. 3, p. 95-102.

Perutz, M.F. 1950. Direct measurement of the velocity distribution in a vertical profile through a glacier. Journal of Glaciology, Vol. 1, No. 7, p. 382-83.

Reeh, N. 1985. Was the Greenland ice sheet thinner in the late Wisconsinan than now? Nature, Vol. 317 , No. 6040, p. 797-99.

Renaud, A. 1949. A contribution to the study of the glacier grain. Journal of Glaciology, Vol. 1, No. 6, p. 320-24.

Rigsby, G.P. 1958. Effect of hydrostatic pressure on velocity of shear deformation of single ice crystals. Journal of Glaciology, Vol. 3, No. 24, p. 273-78.

Robin, G. de Q. 1953. The Norwegian-British-Swedish Antarctic Expedition, 1949-52. II. Summary of seismic shooting investigations in Dronning Maud Land. Journal of Glaciology, Vol. 2, No. 13, p. 205-11.

Robin, G. de Q. 1955. Ice movement and temperature distribution in glaciers and ice sheets. Journal of Glaciology, Vol. 2, No. 18, p. 523-32.

Roch, A. 1954. The glaciers, snow and avalanches of Mount Everest. Journal of Glaciology, Vol. 2, No. 16, p. 428-30.

Röthlisberger, H. 1955. Studies in glacier physics on the Penny Ice Cap, Baffin Island, 1953. Part III: Seismic sounding. Journal of Glaciology, Vol. 2, No. 18, p. $539-52$.

Schaefer, V.J. 1950. A new method for studying the structure of glacier ice. Journal of Glaciology, Vol. 1, No. 8, p. 441-42.

Schytt, V. 1953. The Norwegian-British-Swedish Antarctic Expedition, 1949-52. I. Summary of the glaciological work. Journal of Glaciology, Vol. 2, No. 13, p. 204-05.

Seligman, G. 1941. The structure of a temperate glacier. A résume of the glaciological research made by Dr. T.P. Hughes, Dr. Max Perutz, and the author at the Jungfraujoch. Geographical Journal, Vol. 97, No. 5, p. 295-317.

Seligman, G. 1947. Extrusion flow in glaciers. Journal of Glaciology, Vol. 1, No. 1, p. 12-21.

Sharp, R.P. 1948. Constitution of valley glaciers. Journal of Glaciology, Vol. 1, No. 4, p. 182-89.

Sharp, R.P. 1951. Thermal regimen of firn on upper Seward Glacier, Yukon Territory, Canada. Journal of Glaciology, Vol. 1, No. 9, p. 476-87.

Sharp, R.P. 1953. Glaciers. Eugene, University of Oregon Press.
Sharp, R.P. 1954. Glacier flow: a review. Bulletin of the Geological Society of America, Vol. 65, No. 9, p. 821-38.

Shoji, H., and Langway, 'C.C., jr. 1985. Mechanical properties of fresh ice core from Dye 3, Greenland. (In Langway, C.C., jr, and others, eds. Greenland ice core: geophysics, geochemistry, and the environment. Edited by C.C. Langway, Jr, $H$. Oeschger, and W. Dansgaard. Washington, American Geophysical Union, p. 39-48. (Geophysical Monograph 33.))

Shumskiy, P.A. 1955. Osnovy strukturnogo ledovedeniva [Principles of structural glaciology]. Moscow, Izdatel'stvo Akademii Nauk SSSR. [English translation: New York, Dover Publications, 1964.]

Shumskiy, P.A. 1957. Glaciological and geomorphological reconnaissance in the Antarctic in 1956. Journal of Glaciology, Vol. 3, No. 21, p. 56-61.

Shumskiy, P.A. 1959. Is Antarctica a continent or an archipelago? Journal of Glaciology, Vol. 3, No. 26, p. 455-57.

Steinemann, S. 1954. Results of preliminary experiments on the plasticity of ice crystals. Journal of Glaciology, Vol. 2 , No. 16 , p. 404-13.

Streiff-Becker, R. 1951. Pot-holes and glacier mills. Journal of Glaciology, Vol. 1, No. 9, p. 488-90.

Streiff-Becker, R. 1953. Extrusion flow in glaciers. Journal of Glaciology, Vol. 2, No. 13, p. 181-82.

Suggate, R.P. 1950. Franz Josef and other glaciers of the Southern Alps, New Zealand. Journal of Glaciology, Vol. 1, No. 8, p. 422-29.

Symposium. 1951[a]. Symposium on the Crystallization of Metals, Rocks and Ice. Journal of Glaciology, Vol. 1, No. 10, p. 564-73.

Symposium. 1951[b]. Symposium on the Deposition of Ice on Exposed Surfaces. Journal of Glaciology, Vol. 1, No 10, p. $536-50$.

Symposium. 1975. Symposium on Remote Sensing in Glaciology, Cambridge, 16-20 September 1974. Journal of Glaciology, Vol. 15, No. 73, p. 1-482.

Symposium. 1978. Symposium on the Physics and Chemistry of Ice, Cambridge, 12-16 September 1977. Journal of Glaciology, Vol. 21, No. 85, p. 1-714.

Symposium. 1979. Symposium on Glacier Beds: the Ice-Rock Interface, Ottawa, 15-19 August 1978. Journal of Glaciology, Vol. 23, No. 89, p. 1-445.

Thorarinsson, S. 1953. Some new aspects of the Grimsvötn problem. Journal of Glaciology, Vol. 2, No. 14, p. 267-75.

Untersteiner, N. 1955. Some observations on the banding of glacier ice. Journal of Glaciology, Vol. 2, No. 17, p. 502-06.

Ward, W.H. 1952[a]. The glaciological studies of the Baffin Island Expedition, 1950. Part II: The physics of deglaciation of central Baffin Island. Journal of Glaciology, Vol. 2, No. 11, p. 9-22

Ward, W.H. 1952[b]. The glaciological studies of the Baffin Island Expedition, 1950. Part III: Equipment and techniques. Journal of Glaciology, Vol, 2, No. 12, p. $115-21$

Ward, W.H. 1954. Studies in glacier physics on the Penny Ice Cap, Baffin Island, 1953. Part II: Portable ice-boring equipment. Journal of Glaciology, Vol. 2, No. 16, p. 433-36.

Ward, W.H. 1955. Studies in glacier physics on the Penny Ice Cap, Baffin Island, 1953. Part IV: The flow of Highway Glacier. Journal of Glaciology, Vol. 2, No. 18, p. $592-99$.

Ward, W.H., and Baird, P.D. 1954. Studies in glacier physics on the Penny Ice Cap, Baffin Island, 1953. Part I: A description of the Penny Ice Cap, its accumulation and ablation. Journal of Glaciology, Vol. 2, No. 15, p. $342-55$.

Weeks, W.F., and Anderson, D.L. 1958. Sea ice thrust structures. Journal of Glaciology, Vol. 3, No. 23, p. 173-75.

Wexler, H. 1960. Heating and melting of floating ice shelves. Journal of Glaciology, Vol. 3, No. 27, p. 626-45.

Wood, P. 1986. The International Glaciological Society: fifty years of progress. Cambridge, International Glaciological Society. 
Journal of Glaciology

Zwally, H.J. 1987. Technology in the advancement of glaciology. Journal of Glaciology, Special Issue, p. 66-77. 